Research Paper

\title{
Th2-Associated Alternative Kupifer Cell Activation Promotes Liver Fibrosis without Inducing Local Inflammation
}

\author{
Giuliana López-Navarrete ${ }^{{ }^{*}}$, Espiridión Ramos-Martínez ${ }^{*}$, Karina Suárez-Álvarez¹, Jesús Aguirre-García ${ }^{3}$, \\ Yadira Ledezma-Soto ${ }^{4}$, Sonia León-Cabrera5, Marco Gudiño-Zayas², Carolina Guzmán ${ }^{1}$, Gabriela Gutiér- \\ rez-Reyes ${ }^{2}$, Joselín Hernández-Ruíz', Ignacio Camacho-Arroyo6, Guillermo Robles-Díaz², David Kershe- \\ nobich ${ }^{2}$, Luis I. Terrazas ${ }^{4}$ and Galileo Escobedo ${ }^{1 凶}$
}

1. Unidad de Medicina Experimental, Hospital General de México, México D.F. 06726, México.

2. Departamento de Medicina Experimental, Facultad de Medicina, Universidad Nacional Autónoma de México, Hospital General de México, México D.F. 06726, México.

3. Unidad de Patología, Hospital General de México, Facultad de Medicina, Universidad Nacional Autónoma de México, México D.F. 06726, México.

4. Unidad de Biomedicina, Facultad de Estudios Superiores-Iztacala, Universidad Nacional Autónoma de México, Estado de México 54090, México.

5. Departamento de Microbiología y Parasitología, Facultad de Medicina, Universidad Nacional Autónoma de México, México D.F. 04510, México.

6. Facultad de Química, Departamento de Biología, Universidad Nacional Autónoma de México, México D.F. 04510, México.

* These authors are alphabetically ordered and equally contributed to this work.

$\square$ Corresponding author: G. Escobedo Ph.D., Unidad de Medicina Experimental, Hospital General de México. Dr. Balmis \#148, Col. Doctores, C.P. 06726, México D.F., México. Tel: (52)-55-56232673, ext. 39920. Fax: (52)-55-56232699, ext. 39927. E-mail: gescobedo@unam.mx, gescobedog@msn.com.

(c) Ivyspring International Publisher. This is an open-access article distributed under the terms of the Creative Commons License (http://creativecommons.org/ licenses/by-nc-nd/3.0/). Reproduction is permitted for personal, noncommercial use, provided that the article is in whole, unmodified, and properly cited.

Received: 2011.09.01; Accepted: 2011.10.01; Published: 2011.10.25

\begin{abstract}
Cirrhosis is the final outcome of liver fibrosis. Kupffer cell-mediated hepatic inflammation is considered to aggravate liver injury and fibrosis. Alternatively-activated macrophages are able to control chronic inflammatory events and trigger wound healing processes. Nevertheless, the role of alternative Kupffer cell activation in liver harm is largely unclear. Thus, we evaluated the participation of alternatively-activated Kupffer cells during liver inflammation and fibrosis in the murine model of carbon tetrachloride-induced hepatic damage. To stimulate alternative activation in Kupffer cells, 20 Taenia crassiceps (Tc) larvae were inoculated into BALBc/AnN female mice. Six weeks post-inoculation, carbon tetrachloride or olive oil were orally administered to Tc-inoculated and non-inoculated mice twice per week during other six weeks. The initial exposure of animals to $T$. crassiceps resulted in high serum concentrations of IL-4 accompanied by a significant increase in the hepatic mRNA levels of Ym-I, with no alteration in iNOS expression. In response to carbon tetrachloride, recruitment of inflammatory cell populations into the hepatic parenchyma was 5-fold higher in non-inoculated animals than Tc-inoculated mice. In contrast, carbon tetrachloride-induced liver fibrosis was significantly less in non-inoculated animals than in the Tc-inoculated group. The latter showed elevated IL-4 serum levels and low IFN- $\gamma$ concentrations during the whole experiment, associated with hepatic expression of IL-4, TGF- $\beta$, desmin and $\alpha$-sma, as well as increased mRNA levels of Arg-I, Ym-I, FIZZ-I and MMR in Kupffer cells. These results suggest that alternative Kupffer cell activation is favored in a Th2 microenvironment, whereby such liver resident macrophages could exhibit a dichotomic role during chronic hepatic damage, being involved in attenuation of the inflammatory response but at the same time exacerbation of liver fibrosis.
\end{abstract}


Key words: Liver fibrosis, cirrhosis, Kupffer cell, alternative macrophage activation.

\section{Introduction}

Liver fibrosis is a wound healing process characterized by altered production and accumulation of extracellular matrix proteins (ECM) in the hepatic parenchyma, such as type I and III collagen, laminin, elastin, fibronectin and undulin [1]. In the most advanced stages, liver fibrosis leads to cirrhosis, portal hypertension, liver failure and death [2]. In Western countries, cirrhosis is the seventh leading cause of death [3], whereas in Latin America it still represents a serious public health problem associated with high mortality rates $(\sim 55 / 100,000$ men and $14 / 100,000$ women) [4].

Liver fibrosis results from chronic hepatic injury [5]. Kupffer cells, the resident macrophages of the liver, have been demonstrated to decisively mediate wound-related hepatic inflammation, and consequently initiate liver fibrosis $[1,6,7]$. In response to liver damage agents, including harmful use of alcohol, hepatitis $C$ virus infection (HCV) and non-alcoholic steatohepatitis, Kupffer cells are activated starting to express proinflammatory cytokines such as tumor necrosis factor alpha (TNF- $\alpha$ ), interleukin (IL) $1 \beta$ and IL-6, several chemoattractant molecules as it is the case for monocyte chemotactic protein 1 (MCP-1) and CXCL8 [8], and some enzymes, such as the inducible nitric oxide synthase (iNOS) [9]. Consequently, additional immune cells are recruited into the liver that shows active infiltration of $\mathrm{CD}^{+}$ and $\mathrm{CD}^{+} \mathrm{T}$ lymphocytes, natural killer cells, and neutrophils associated with high levels of interferon-gamma (IFN- $\gamma$ ) and IL-12 [5-10]. As a result of this inflammatory scenario, Kupffer cells also synthesize profibrogenic factors, such as transforming growth factor beta 1 (TGF- $\beta 1$ ) capable of activating the hepatic stellate cells (HSC), considered to be the most important ECM-producing cells in the injured liver [2, 11]. Thus, the participation of Kupffer cells in the pathogenesis of chronic hepatic fibrosis has been mainly related with hepatic inflammation and activation of HSC [2]. However, a solid body of growing evidence suggests that liver resident Kupffer cells could have additional roles during liver damage, when they display an alternative activation status [12, 13].

Kupffer cells, as the rest of the macrophages, can be differentially activated depending on the cytokine microenvironment $[12,13]$. Kupffer cells exposed to Type 1 cytokines, including IL-12 and IFN- $\gamma$, exert a classical state of activation associated with proinflammatory responses through expression of TNF- $\alpha$,
IL-6, IL-1 $\beta$, MCP-1, and iNOS [14, 15]. In contrast, alternatively-activated Kupffer cells have the ability to express arginase (Arg), chitinase (Ym) and IL-10 in order to promote tissue repair and ameliorate excessive inflammation in response to the Th2-cytokines IL-4 and IL-13 [14-16]. Although the actions of classical Kupffer cells have been broadly described in chronic hepatic diseases [1, 2, 5-11], the role of alternatively-activated Kupffer cells during liver inflammation and fibrosis remains elusive and controversial $[12,13,16-20]$. For instance, recent evidence implicates activity of alternative Kupffer cells with restriction of fibrosis [17, 18]. In this sense, Type 1 IL-4 Receptor-deficient mice exhibit an impaired alternative activation in Kupffer cells, which correlates with increased liver inflammation, fibrosis, and death during acute schistosomiasis by Schistosoma mansoni [18]. Similarly, IL-4-activated alternative Kupffer cells improve both steatohepatitis and fibrosis during experimental and human non-alcoholic fatty liver disease $[12,13]$. On the contrary, other information correlates alternatively-activated Kupffer cells with more severe fibrogenic response. To this respect, S. mansoni-infected IL-21\%- knockout mice show decreased hepatic fibrosis clearly associated with low expression of IL-4, IL-13, and other markers of alternative Kupffer cell activation, such as Ym-1 and FIZZ-1 (found in inflammatory zone 1, also known as RELM $\alpha$ ) [19]. Likewise, liver tissue from IL-5/- deficient mice displays less fibrosis in response to $S$. mansoni eggs when Kupffer cells exhibit a classic activation status, denoted by diminished mRNA levels of Arg-1, Ym-1, and FIZZ-1 [20]. Therefore, more experimental evidence is necessary in order to clarify the function of alternative activation on Kupffer cells during liver injury and fibrogenesis.

Helminth parasites are able to stimulate alternative activation in murine and human macrophages $[21,22]$. Inoculation of Taenia crassiceps larvae (ORF strain) into the peritoneal cavity of BALB/c female mice is able to bias the host immune response toward a Th2-type profile, characterized by activation of the STAT6 signaling pathway in immune cells, elevation of IL- 4 and IL-13, and a decrease in the IFN- $\gamma$ and IL-12 serum levels after six weeks post-inoculation [23]. As it has been shown, this cytokine profile is directly involved in alternative activation of murine macrophages that display overexpression of Arg-1, Ym-1, FIZZ-1, and MMR (macrophage mannose receptor) [24-26]. Due to its simplicity and reproduci- 
bility, this experimental strategy has become a convenient model for studying the anti-inflammatory properties of alternatively-activated peritoneal macrophages during several chronic inflammatory diseases, such as experimental autoimmune encephalomyelitis and streptozotocin-induced type 1 diabetes $[27,28]$. However, besides their well described immunosuppressive characteristics, alternative macrophages could adopt other functions as wound healer cells with important implications during the pathogenesis of hepatic fibrosis, as it has also been suggested for peritoneal and lung fibrosis [29-32].

Thus, the main purpose of this work was to evaluate the role of alternative Kupffer cell activation upon carbon tetrachloride-induced liver inflammation and fibrosis in a T. crassiceps-induced Th2 mouse model. Our findings may contribute to a better understanding of the immune mechanisms leading hepatic tissue-resident macrophages to mediate repair process during liver damage that could be associated with a persistent fibrogenic response and cirrhosis progression.

\section{Materials and Methods}

\section{Mice}

Female mice (Mus musculus, strain BALB/cAnN) aged between 6-8 weeks were used in all of our experiments. Animals were fed with Purine Diet 5015 (Purine, St. Louis, MO) and water ad libitum throughout all of the experimental time. All experimental procedures were approved by the Ethical Committees of the Hospital General de México and the Facultad de Medicina of the Universidad Nacional Autónoma de México, according to the University Animal Care and Use Committee.

\section{T. crassiceps inoculation}

A parasite stock of $T$. crassiceps (ORF-Kuhn2 strain) [33] larvae was donated to our laboratory by Dr. L.I. Terrazas, and preserved by serial intraperitoneal passage in BALBc/AnN female mice every three months. T. crassiceps larvae for each experimental session were obtained from one donor female mouse and placed in tubes containing sterile PBS 1X, supplemented with $100 \mathrm{U} / \mathrm{ml}$ of penicillin-streptomycin-fungizone (Gibco, Grand Island). $T$. crassiceps larvae were then centrifuged for $10 \mathrm{~min}$ at $1200 \mathrm{rpm} / 4^{\circ} \mathrm{C}$, discarding the supernatant at the end of this interval. This procedure was repeated 3 times using non-supplemented sterile PBS 1X. Finally, packed $T$. crassiceps larvae were placed in fresh sterile PBS 1X and twenty viable non-budding $T$. crassiceps larvae of approximately $2 \mathrm{~mm}$ in diameter were selected for being separately inoculated into the peritoneal cavity of different female mice (Tc-inoculated), using a 21GX32 mm needle (DL Medica, México). Non-inoculated control female mice only received 400 $\mu \mathrm{L}$ of sterile PBS $1 \mathrm{X}$. Six weeks post-inoculation, ten Tc-inoculated and ten non-inoculated control animals were euthanized for determination of the IL-4 and IFN- $\gamma$ serum levels, as well as evaluation of $Y \mathrm{~m}-1$ and iNOS expression in liver tissue.

\section{Experimental groups design and carbon tet- rachloride administration}

Six weeks post-inoculation, forty female mice (ten animals per group) were subjected to four different treatments as follows: a) animals previously inoculated with $20 \mathrm{~T}$. crassiceps larvae orally received carbon tetrachloride (J.T. Baker, Mexico), $2 \mathrm{mg} / \mathrm{Kg}$ of body weight, twice per week, during six weeks $\left.\left(\mathrm{Tc}+\mathrm{CCl}_{4}\right) ; \mathrm{b}\right)$ animals previously inoculated with $20 \mathrm{~T}$. crassiceps larvae received olive oil as vehicle orally, twice per week, during six weeks $(\mathrm{Tc}+\mathrm{V})$; c) animals previously treated with $400 \mu \mathrm{L}$ of sterile PBS 1 X orally received $\mathrm{CCl}_{4}, 2 \mathrm{mg} / \mathrm{Kg}$ of body weight, twice per week, during six weeks $\left(\mathrm{CCl}_{4}\right)$; d) finally, animals previously treated with $400 \mu \mathrm{L}$ of sterile PBS 1 X orally received olive oil as vehicle twice per week during six weeks $(V)$. All experimental groups were euthanized six weeks after carbon tetrachloride or vehicle treatment, using a $\mathrm{CO}_{2}$-saturated chamber for blood and liver samples collection, as well as for the determination of the number of larvae.

\section{Assessment of the liver inflammation and fi- brosis by histological examination}

Liver samples were collected from all experimental groups, and placed in $4 \%$ paraformaldehyde (J.T. Baker, Mexico) for 2 weeks. Briefly, tissues were washed twice with PBS 1X solution (Sigma-Aldrich, USA). They were then dehydrated using $70 \%, 80 \%$, $95 \%$, and $100 \%$ ethanol (J.T. Baker, Mexico), in separate incubations of 15 minutes each. Subsequently, tissues were placed into xylene (J.T. Baker, Mexico) for $30 \mathrm{~min}$ and, after an extra wash with PBS 1X, embedded in $60^{\circ} \mathrm{C}$ liquid paraffin during $30 \mathrm{~min}$. After this time, liquid paraffin was replaced with new fresh $60^{\circ} \mathrm{C}$ paraffin. Once the blocks were solidified after 24 $\mathrm{h}$ at room temperature, the liver tissue was cross-sectioned in $4 \mu \mathrm{M}$ slices using a microtome (Microtome Olympus Cut 4060, USA). Liver sections were separately stained with hematoxylin-eosin or Sirius red for evaluation of the inflammatory infiltrate and liver fibrosis, respectively. According to the microscopic characteristics of the nucleus, the inflam- 
matory infiltrate was determined by an expert pathologist as number of polymorphonuclear leukocytes per one hundred hepatocytes in a single-blind test. Liver fibrosis was quantified as percentage of Sirius red area, where yellow scars correspond to type I collagen, and green scars correspond to type III collagen. Stage of liver fibrosis was assessed by an expert pathologist in a single-blind test according to the Metavir Score, where F0 = no fibrosis; F1 = portal fibrosis without septa; F2 = portal fibrosis with few septa; F3 = numerous septa without cirrhosis; F4 = cirrhosis. Microphotographs were acquired at 20, 40, and 100x magnification, using a Nikon Microphot-FXA microscope coupled to a Nikon Digital Camera DXM1200F. Digital images from hematoxylin-eosin and Sirius red staining were analyzed by means of the MATLAB 7.1 software.

\section{Serum levels of IL-4 and IFN- $\gamma$ by ELISA}

Blood samples from all experimental groups were collected at room temperature, and centrifuged at $1200 \mathrm{rpm} / 30 \mathrm{~min}$. Sera were separated and stored at $-70^{\circ} \mathrm{C}$ until use. Briefly, after blocking during $1 \mathrm{~h}$ with $10 \%$ FCS in PBS $1 \mathrm{X}$ pH 7.0, each well was washed 3 times, and standard solutions, as well as 50 $\mu \mathrm{L}$ of each serum sample, were separately added to a 96-well microplate (Costar), previously coated with specific IL-4 and IFN- $\gamma$ capture antibodies (Peprotech, Mexico) during $2 \mathrm{~h}$ at $37^{\circ} \mathrm{C}$. Biotin-labeled secondary antibodies were then added to each well during $1 \mathrm{~h}$ at $37^{\circ} \mathrm{C}$. Each well was washed 5 times and Streptavidin-AKP (PharMingen, USA), as conjugate solution, was added during $30 \mathrm{~min}$ at $37^{\circ} \mathrm{C}$. After this time, a final wash was performed 6 times, and p-Nitrophenyl Phosphate (BioLabs, Inc.) in Glycine buffer was added and incubated during $30 \mathrm{~min}$ at $37^{\circ} \mathrm{C}$. Concentration of both studied cytokines was determined by absorbance at $405 \mathrm{~nm}$ using an automatic ELISA reader (Thermo Electron Microplate Reader, Mecury Scientific \& Chemicals). Final concentration of each measured cytokine was determined in duplicate, and expressed as mean \pm standard deviation.

\section{Isolation of liver resident Kupffer cells}

Liver resident Kupffer cells were separately isolated by means of the conventional counterflow centrifugal elutriation method. Briefly, $1 \mathrm{~g}$ of each liver sample was perfused with abundant calcium-free Hanks' balanced salt solution (Invitrogen, USA), and gently dispersed on a sterile nylon mesh. Liver suspensions from each experimental group were then pooled and placed into a $0.5 \mathrm{mg} / \mathrm{mL}$ collagenase A solution (Boehrringer-Mannheim, Mannheim, Germany) in RPMI 1640 medium (Gibco BRL, USA) sup- plemented with $5 \%$ fetal calf serum at $35^{\circ} \mathrm{C}$ for $15 \mathrm{~min}$. After this time, liver cell suspensions were separately filtered in a sterile nylon mesh and placed into fresh calcium-free Hanks' balanced salt solution (Invitrogen, USA) for subsequent centrifugation at $250 \mathrm{rpm}$ during $15 \mathrm{~min}$. Once the supernant was discarded, the cell pellet was resuspended in $10 \mathrm{~mL}$ calcium-free Hanks' balanced salt solution with $15 \mathrm{~mL}$ NycoPrep ${ }^{\mathrm{TM}}$ 1.068 (Gibco BRL, USA). The red blood cell fraction was sedimented at $1000 \mathrm{rpm}$ for $10 \mathrm{~min}$, and cells from the interphase were placed in $20 \mathrm{~mL}$ calcium-free Hanks' balanced salt solution to be subsequently centrifuged at $2000 \mathrm{rpm}$ during $15 \mathrm{~min}$. The cell pellet was resuspended in $5 \mathrm{~mL}$ calcium-free Hanks' balanced salt solution, and separated into several cell fractions by counterflow centrifugal elutriation using the Beckman JE-5.0 elutriator rotor, coupled to a Sanderson chamber (Beckman Instruments, CA, USA) at $12 \mathrm{~mL} / \mathrm{min}$ flow rate, using calcium-free Hanks' balanced salt solution with elutriator speed at $3200 \mathrm{rpm}$. The intermediate cell fraction was used for recovering around $2 \times 10^{6}$ Kupffer cells from each pooled experimental group. Purity of Kupffer cell population ( $\sim 90 \%)$ was determined by conventional non-specific esterase and Diff Quick stain using a Nikon Microphot microscope at 100x magnification.

\section{Total RNA extraction by Guanidinium thio- cyanate-phenol-chloroform method}

Liver or isolated Kupffer cell samples from all experimental groups were placed in Trizol reagent (Invitrogen, Carlsbad, California), and stored at $-70^{\circ} \mathrm{C}$ until use. Briefly, the hepatic tissue was disrupted in Trizol reagent $(1 \mathrm{~mL} / 0.1 \mathrm{~g}$ tissue $)$ at $4^{\circ} \mathrm{C} .1 \times 10^{6}$ Kupffer cells were vortexed for $10 \mathrm{~min}$ at $4^{\circ} \mathrm{C}$. Subsequently, $0.2 \mathrm{~mL}$ of cold chloroform per $\mathrm{mL}$ of Trizol were added to each sample. After $10 \mathrm{~min}$ of incubation at $4^{\circ} \mathrm{C}$, and $15 \mathrm{~min}$ of centrifugation at 13000 $\mathrm{rpm} / 4^{\circ} \mathrm{C}$, the aqueous phase from each sample was recovered and separately placed into $1.6 \mathrm{~mL}$ Eppendorf tubes. Total RNA was then precipitated with isopropyl alcohol overnight at $4^{\circ} \mathrm{C}$. After this, RNA samples were centrifuged at $13000 \mathrm{rpm} / 4^{\circ} \mathrm{C}$ during $15 \mathrm{~min}$, and supernatant was discarded. Next, the RNA pellet was washed twice with $100 \%$ pure ethanol,and dissolved in RNAse-free water treated with DEPC (Sigma-Aldrich, USA). RNA concentration was determined by absorbance at $260 / 280 \mathrm{~nm}$, and purity was verified by electrophoresis on $1.0 \%$ denaturing agarose gel (Promega, Uniparts, México) in the presence of $2.2 \mathrm{M}$ formaldehyde. 
mRNA expression levels of IFN- $\gamma$, IL- I 2, IL-4, IL- I3, TNF- $\alpha$, IL- I0, TGF- $\beta$ I, desmin, $\alpha$-sma, Arg-I, Ym-I, FIZZ-I, MMR, and iNOS by RT-PCR

Total RNA samples from hepatic tissue or isolated Kupffer cells were reverse-transcribed by using the M-MLV Retrotranscriptase system and dT primer (Invitrogen, USA). cDNA was specifically amplified by semi-quantitative PCR using TaqDNA polymerase (Biotecnologías Universitarias, UNAM, México), and mouse-specific primers to detect the mRNA levels of Th1-type cytokines (IFN- $\gamma$, IL-12), Th2-type cytokines (IL-4, IL-13), proinflammatory cytokines (TNF- $\alpha$ ), anti-inflammatory cytokines (TGF- $\beta 1$, IL-10), molecular markers for activated HSC (desmin), profibrogenic response-associated markers ( $\alpha$-smooth muscle actin [ $\alpha$-sma]), classic activation markers in macrophages (iNOS), and alternative activation markers in macrophages (Arg-1, Ym-1, FIZZ-1, MMR) (Table 1). 18S-ribosomal RNA was used as a control gene of constitutive expression. Briefly, the $25 \mu \mathrm{L}$ PCR reaction included $2 \mu \mathrm{L}$ of previously synthesized cDNA, 5 $\mu \mathrm{L}$ of 10X PCR-buffer (Perkin-Elmer, USA), $1 \mathrm{mM}$ $\mathrm{MgCl}, 0.2 \mathrm{mM}$ of each dNTP, $0.05 \mu \mathrm{M}$ of each specific primer, $0.5 \mu \mathrm{L}$ of TaqDNA polymerase (Biotecnologías Universitarias, México), and DNAse-free water. After an initial denaturation step at $94^{\circ} \mathrm{C}$ for 5 min, temperature cycling was as follows: $95^{\circ} \mathrm{C}$ for 30 seconds, from $55^{\circ} \mathrm{C}$ to $62^{\circ} \mathrm{C}$ (depending on the primer sequence) for 30 seconds, and $72^{\circ} \mathrm{C}$ for 45 seconds during 30 or 35 cycles (depending on the primer sequence). An extra extension step was completed at $72^{\circ} \mathrm{C} / 10 \mathrm{~min}$ for each amplification session. The $25 \mu \mathrm{L}$ of the PCR reaction were separated by electrophoresis on $2 \%$ agarose gel (Promega, Uniparts, Mexico), and corresponding bands were visualized through stain with ethidium bromide in the presence of a $100 \mathrm{bp}$ ladder as molecular weight marker (Fermentas, Mexico). Relative expression of each amplified gene was obtained by optical density analysis (OD) using the 18S-ribosomal RNA as control gene of constitutive expression.

\section{Experimental design and statistical analysis}

Our results were obtained from two independent experiments. A sufficient number of BALBc/AnN female mice were disposed into different experimental groups, consisting in 10 animals each. Dependent variables were liver fibrosis degree, number of polymorphonuclear leukocytes per one hundred hepatocytes, cytokine concentrations, and mRNA expression levels of IFN- $\gamma$, IL-12, IL-4, IL-13, TNF- $\alpha$, TGF- $\beta 1$, IL-10, desmin, $\alpha$-sma, iNOS, Arg-1, Ym-1, FIZZ-1, and MMR. Independent variables were presence or absence of inoculation with $T$. crassiceps larvae, as well as carbon tetrachloride and vehicle treatment. Data are presented as mean \pm standard deviation, and analyzed by means of the Shapiro-Wilk test for determination of normality. Depending on the number of compared groups, data were analyzed using t-student, or one-way ANOVA, followed by the post-hoc Tukey test, using the GraphPad Prism 5 software. Differences were considered significant when $\mathrm{P}<0.05$.

Table I. Primer sequences for PCR amplification.

\begin{tabular}{|c|c|c|c|}
\hline Gene & Forward Primer & Reverse Primer & Product Length \\
\hline IL-4 & 5'-CGAAGAACACCACAGAGAGTGAGCT-3' & 5'-GACTCATTCATGGTGCAGCTTATCG-3' & 181 \\
\hline IFN- $\gamma$ & 5'-AGCGGCTGACTGAACTCAGATTGTAG-3' & 5'-GTCACAGTTTTCAGCTGTATAGGG-3' & 247 \\
\hline IL-12p40 & 5'-ACATCAGACCAGGCAGCTCGCAG-3' & 5'-GAGTGGCTCAGAGTCTCGCCTCC-3' & 331 \\
\hline IL-10 & 5'-ACCTGGTAGAAGTGATGCCCCAGGCA-3' & 5'-CTATGCAGTTGATGAAGATGTCAAA-3' & 237 \\
\hline TGF- $\beta 1$ & 5'-TACCCGGCGTTCCTCAGACG-3' & 5'-CAGGAGTCGCGGTGAGGCTCTG-3' & 309 \\
\hline TNF- $\alpha$ & 5'-TGGTGCCAGCCGATGGGTTG-3' & 5'-CTGCCCGGACTCCGCAAAGT-3' & 299 \\
\hline Desmin & 5'-GCCCTGGCTATTGGCAGGTGT-3' & 5'-CCATGAGGGCAGTTTTCAGGCC-3' & 233 \\
\hline$\alpha$-sma & 5'-AGCGGGCATCCACGAAACCA-3' & 5'-AGCCAAGATGGAGCCACCGA-3' & 229 \\
\hline Arg-1 & 5'-CAGAAGAATGGAAGAGTCAG-3' & 5'-CAGATATGCAGGGAGTCACC-3' & 250 \\
\hline Ym-1 & 5'-TCACAGGTCTGGCAATTCTTCTG-3' & 5'-TTTGTCCTTAGGAGGGCTTCCTC-3' & 436 \\
\hline FIZZ-1 & 5'-GGTCCCAGTGCATATGGATGAGACCATAG-3' & 5'-CACCTCTTCACTCGAGGGACAGTTGGCAGC-3' & 290 \\
\hline MMR & 5'-GAATAGAGCCAAGGGCGTGGTCG-3' & 5'-CTGCAGGTCAGCAGGTTTAGGC-3' & 391 \\
\hline iNOS & 5'-CTGGAGGAGCTCCTGCCTCATG-3' & 5'-GCAGCATCCCCTCTGATGGTG-3' & 449 \\
\hline $18 \mathrm{~S}$ & 5'-CGCGGTTCTATTTTGTTGGT-3' & 5'-AGTCGGCATCGTTTATGGTC-3' & 219 \\
\hline
\end{tabular}




\section{Results}

Initially, Tc-inoculated and non-inoculated mice were euthanized after six weeks post-inoculation with 20 T. crassiceps larvae or $400 \mu \mathrm{L}$ of sterile PBS $1 X$, respectively. The exposure to $T$. crassiceps induced a significant 10 -fold increase in the IL-4 serum levels from Tc-inoculated animals, when compared with non-inoculated control mice (Fig. 1A). In contrast, the IFN- $\gamma$ levels showed a 4-fold decrease at the same time (Fig. 1B). Furthermore, the hepatic tissue from Tc-inoculated animals displayed a significant 14 -fold increase in Ym-1 expression (Fig. 1C), while the
mRNA levels of iNOS exhibited no variation between both experimental groups (Fig. 1D). It is thus clear that the immune profile from Tc-inoculated mice was polarized toward a Th2-type, which could be associated with the alternative activation microenvironment observed in these animals. At this time, carbon tetrachloride or vehicle started to be administered to a sufficient number of Tc-inoculated animals $\left(\mathrm{Tc}+\mathrm{CCl}_{4}\right.$ and $\mathrm{Tc}+\mathrm{V}$ groups, respectively) during six weeks. Parallel, non-inoculated control mice were subjected to this same experimental scheme $\left(\mathrm{CCl}_{4}\right.$ and $\mathrm{V}$ groups, respectively).
A

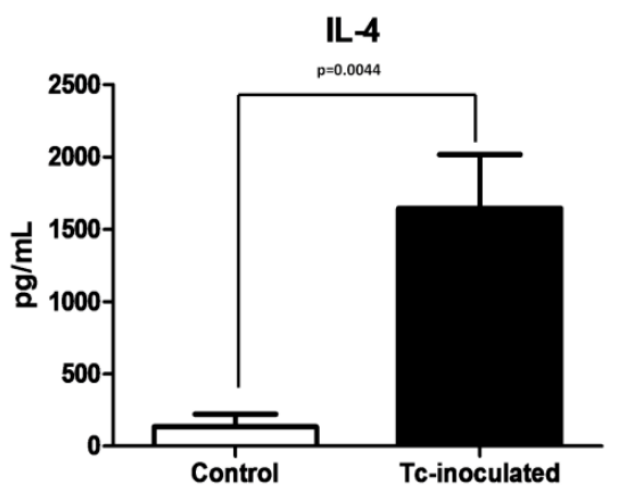

$\mathrm{C}$

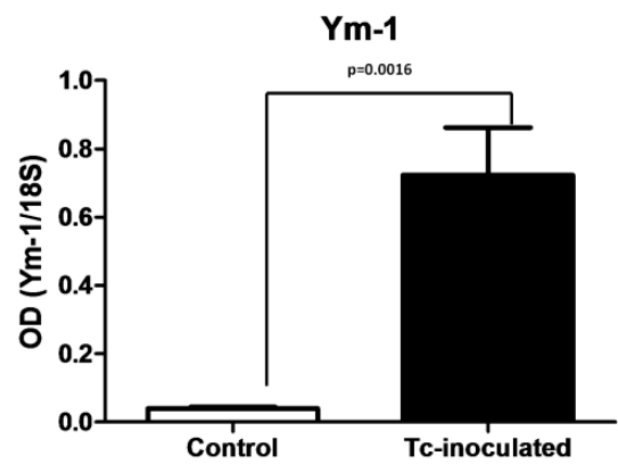

B

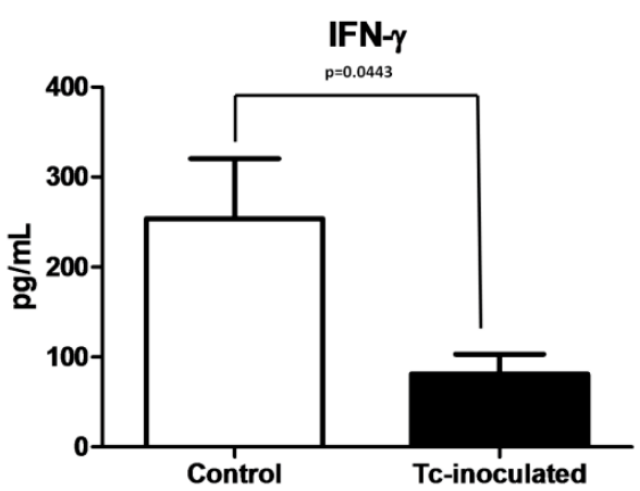

$\mathrm{D}$

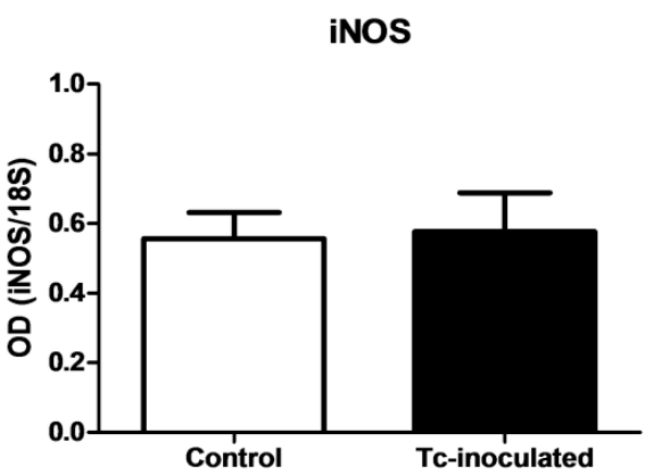

Figure I. T. crassiceps-inoculation induces elevation of IL-4 and hepatic expression of Ym-I. Six weeks post-inoculation, IL-4 (A) and IFN- $\gamma$ (B) serum levels were determined from Tc-inoculated and non-inoculated mice by ELISA. Ym-I (C) and iNOS (D) expression was directly measured from the hepatic tissue of both animal groups by RT-PCR. Tc-inoculated = mice inoculated with $T$. crassiceps; Control $=$ non-inoculated mice treated with $400 \mu \mathrm{L}$ of sterile PBS IX. Results from C and D are presented as optical densitometry (OD) using I8S as control gene of constitutive expression. Data were obtained from 2 independent experiments ( 10 animals per group), and expressed as mean \pm standard deviation. Data were considered significant when $\mathrm{P}<0.05$. 
After six weeks of carbon tetrachloride or vehicle treatment, the number of larvae located at the peritoneal cavity of $\mathrm{Tc}+\mathrm{CCl}_{4}$ and $\mathrm{Tc}+\mathrm{V}$ subjects revealed no significant differences $(412 \pm 81$ and $378 \pm 65$, respectively). It is important to say that the presence of $T$. crassiceps was not related to hepatic damage, since neither inflammation nor fibrosis was observed in the liver of $\mathrm{Tc}+\mathrm{V}$ animals (Figs. 2A and 3B). However, the $\mathrm{CCl}_{4}$ mice group showed an increase in the inflam- matory cell recruitment into the liver ( $\sim 50$ polymorphonuclear leukocytes per 100 hepatocytes, predominantly neutrophils) when compared with $\mathrm{V}$ and $\mathrm{Tc}+\mathrm{V}$ healthy groups (Fig. 2B). In contrast, when carbon tetrachloride was administered to Tc-inoculated subjects, a scarce infiltration of polymorphonuclear leukocytes was denoted at the hepatic parenchyma of these animals (Fig. 2B).
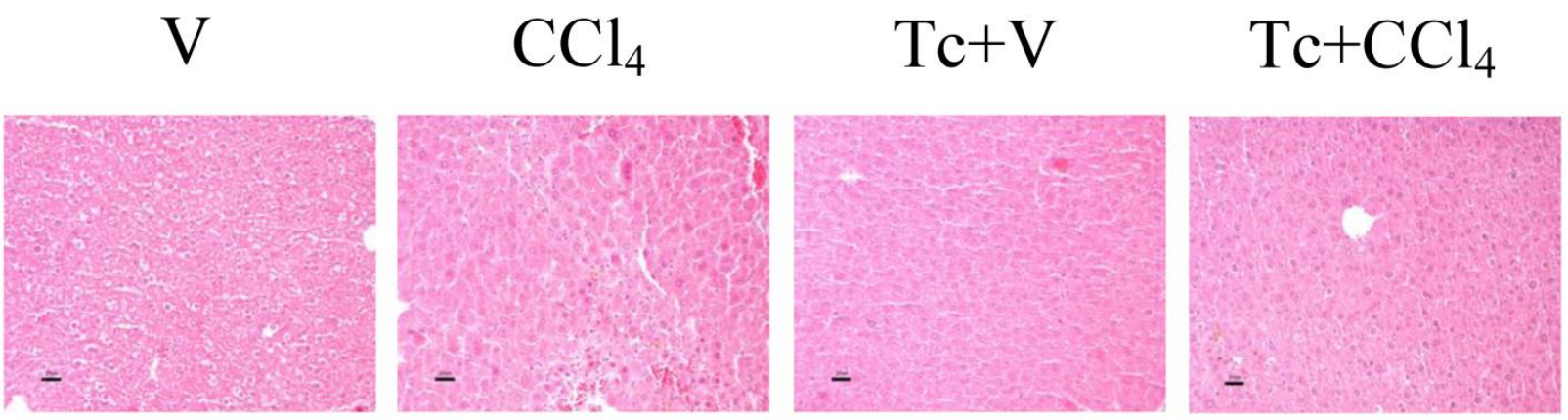

\section{$\mathrm{B}$}

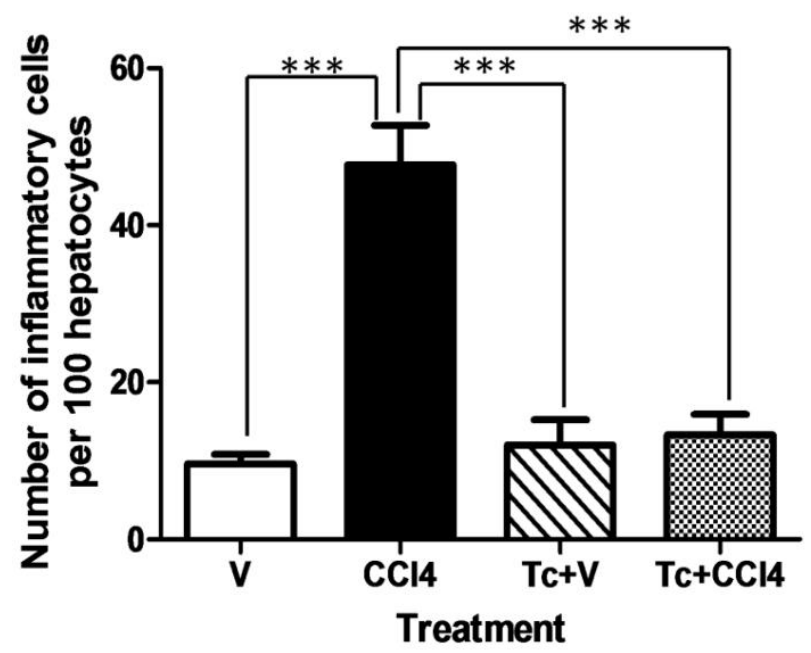

Figure 2. T. crassiceps-inoculation prevents recruitment of inflammatory cells into the liver in response to carbon tetrachloride. Tc-inoculated and non-inoculated mice orally received carbon tetrachloride or olive oil twice per week during six weeks. (A) Liver sections from all experimental groups were stained with hematoxylin-eosin. (B) The inflammatory infiltrate was quantified as number of polymorphonuclear leukocytes per one hundred hepatocytes in a single-blind test. $V=$ non-inoculated mice receiving olive oil as vehicle; $\mathrm{CCl}_{4}=$ non-inoculated mice receiving carbon tetrachloride; $\mathrm{Tc}+\mathrm{V}=$ mice previously inoculated with $T$. crassiceps receiving olive oil; $\mathrm{Tc}_{c}+\mathrm{CCl}_{4}=$ mice previously inoculated with $T$. crassiceps receiving carbon tetrachloride. Scale bar $=20 \mu \mathrm{M}$. Data were obtained from 2 independent experiments ( 10 animals per group), and expressed as mean \pm standard deviation. $* * * P<0.0001$.

Unexpectedly, the Sirius red stain revealed that $\mathrm{Tc}+\mathrm{CCl}_{4}$ mice displayed a more active profibrogenic response in relation with $\mathrm{V}, \mathrm{Tc}+\mathrm{V}$ and $\mathrm{CCl}_{4}$ animal groups (Fig. 3A and B). The percentage of type I col- lagen from $\mathrm{Tc}+\mathrm{CCl}_{4}$ liver sections was around $8.5 \%$, while type III collagen represented $4 \%$ from each analyzed sample (Fig. 3C). On the contrary, $\mathrm{CCl}_{4}$ mice showed approximately $3.7 \%$ and $0.34 \%$ of type I and 
III collagen, respectively (Fig. 3C). According to the Metavir Score, $65 \%$ of the $\mathrm{Tc}+\mathrm{CCl}_{4}$ experimental subjects exhibited a severe stage of liver fibrosis (F3), whilst 35\% showed an intermediate degree (F2), after six weeks of carbon tetrachloride administration (Table 2). At the same time, most of the $\mathrm{CCl}_{4}$ group $(83 \%)$ presented a consistent mild stage of liver fibrosis (F1), and only around $16.7 \%$ developed a moderate degree (F2) of ECM accumulation at the hepatic parenchyma (Table 2). Although liver collagen content was significantly higher in $\mathrm{CCl}_{4}$ animals than in $\mathrm{V}$ and $\mathrm{Tc}+\mathrm{V}$ healthy controls (F0), it was noticeably 3 -fold less in relation to that observed in the hepatic tissue from $\mathrm{Tc}+\mathrm{CCl}_{4}$ mice (Fig. 3C).

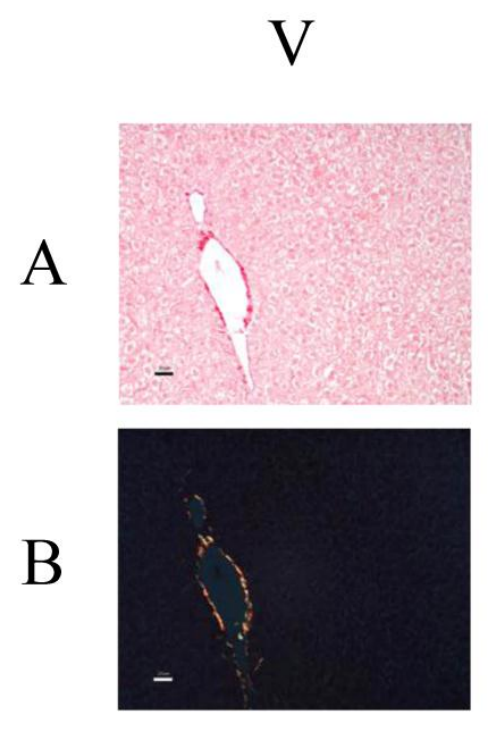

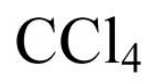
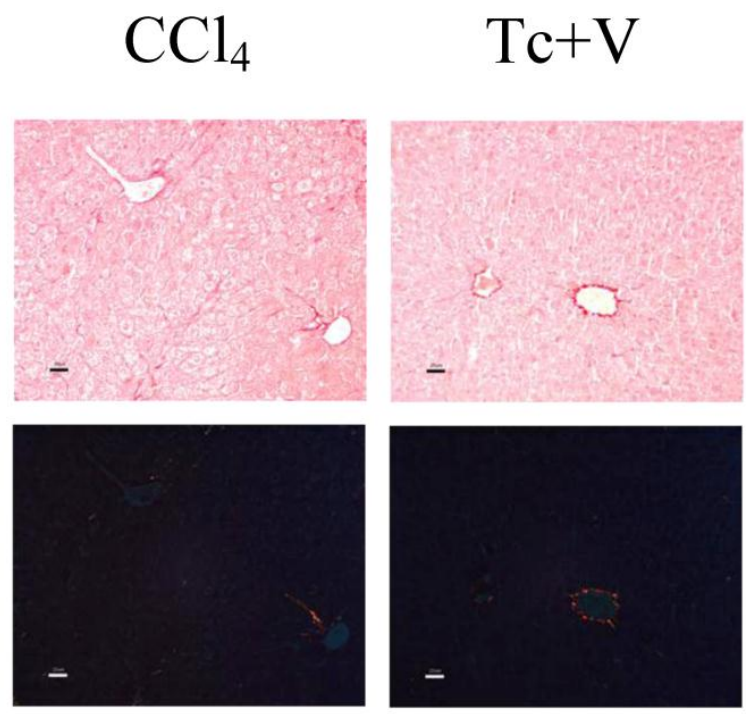
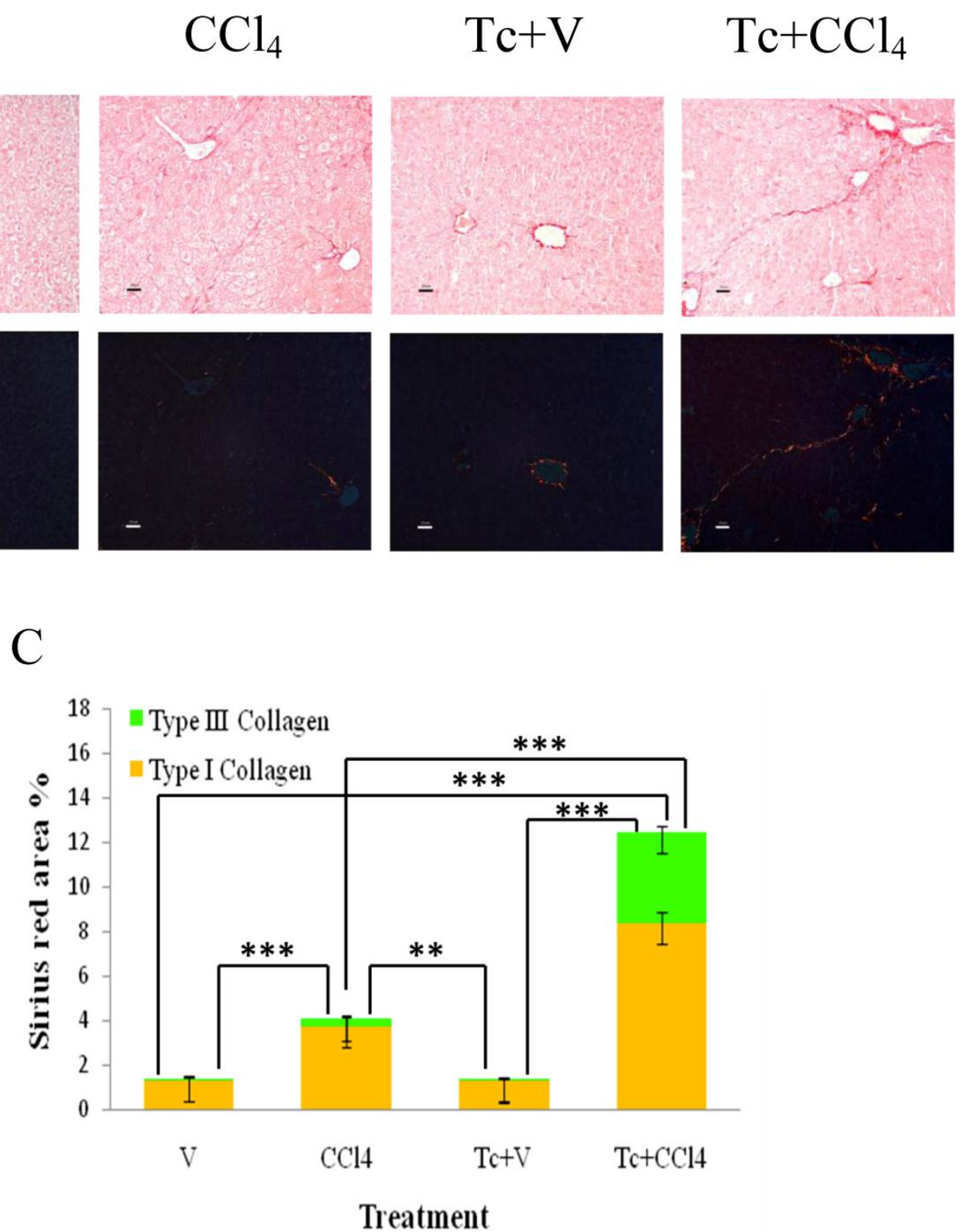

Figure 3. T. crassiceps-inoculation aggravates liver fibrosis in response to carbon tetrachloride. Tc-inoculated and non-inoculated mice orally received carbon tetrachloride or olive oil twice per week during six weeks. (A) Liver sections from all experimental groups were stained with Sirius red for fibrosis assessment. (B) Sirius red staining under polarized light for determination of type I (yellow scars) and III (green scars) collagen. (C) Content of hepatic collagen from all experimental groups was quantified as percent of Sirius red area using the MATLAB 7.1 software in a single-blind test. $V=$ non-inoculated mice receiving olive oil as vehicle; $\mathrm{CCl}_{4}=$ non-inoculated mice receiving carbon tetrachloride; $\mathrm{Tc}+\mathrm{V}=$ mice previously inoculated with $T$. crassiceps receiving olive oil; $T_{c}+\mathrm{CCl}_{4}=$ mice previously inoculated with $T$. crassiceps receiving carbon tetrachloride. Scale bar $=20 \mu \mathrm{M}$. Data were obtained from 2 independent experiments ( 10 animals per group), and expressed as mean \pm standard deviation. $* * \mathrm{P}<0.00 \mathrm{I}$. $* * * \mathrm{P}<0.000 \mathrm{I}$. 
Table 2. Liver fibrosis degree from all experimental groups according to the Metavir Score. Data are presented as percentage.

\begin{tabular}{lllll}
\hline \multicolumn{2}{l}{ Treatment } & & \\
\hline Liver fibrosis degree & $\mathrm{V}$ & $\mathrm{CCl}_{4}$ & $\mathrm{Tc}+\mathrm{V}$ & $\mathrm{Tc}+\mathrm{CCl}_{4}$ \\
F0 & $100(20 / 20)$ & 0 & $100(20 / 20)$ & 0 \\
F1 & 0 & $83.3(15 / 18)$ & 0 & 0 \\
F2 & 0 & $16.6(3 / 18)$ & 0 & $35.3(6 / 17)$ \\
F3 & 0 & 0 & 0 & $64.7(11 / 17)$ \\
F4 & 0 & 0 & 0 & 0 \\
\hline
\end{tabular}

In order to confirm that neither carbon tetrachloride administration nor the whole duration of the experiment modified the levels of Th1 and Th2-type cytokines, serum concentrations of IL-4 and IFN- $\gamma$ were measured again from each experimental group of mice (Fig. 4). The levels of IL-4 remained significantly increased in both $\mathrm{Tc}+\mathrm{V}$ and $\mathrm{Tc}+\mathrm{CCl}_{4}$ animals, when compared to their corresponding $\mathrm{V}$ and $\mathrm{CCl}_{4}$ rodent groups (Fig. 4A). In contrast, the IFN- $\gamma$ concentration was considerably augmented in the $\mathrm{CCl}_{4}$ group, while $\mathrm{Tc}+\mathrm{V}$ and $\mathrm{Tc}+\mathrm{CCl}_{4}$ mice exhibited reduced levels of this Th1-type cytokine at the end of the experiment (Fig. 4B).

Such Th2-biased cytokine profile favored the establishment of an alternative activation microenvironment at the liver of $\mathrm{Tc}+\mathrm{V}$ and $\mathrm{Tc}+\mathrm{CCl}_{4}$ subjects. In fact, the hepatic expression of IL-4 was clearly induced by the presence of T. crassiceps (Fig. 4C), with no alteration in the expression levels of IFN- $\gamma$ (Fig. $4 \mathrm{D})$. On the contrary, the IL-12 expression was evidently associated with exposure to carbon tetrachloride, as $\mathrm{CCl}_{4}$ and $\mathrm{Tc}+\mathrm{CCl}_{4}$ mice exhibited a 3-fold increase when compared to $\mathrm{V}$ and $\mathrm{Tc}+\mathrm{V}$ rodent groups (Fig. 4E). The expression of IL-10 did not exhibit any significant modification throughout all studied animal groups (Fig. 4F). In a similar way, expression of TNF- $\alpha$ was not modified by the carbon tetrachloride administration, nor was it due to inoculation with $T$. crassiceps (Fig. $4 \mathrm{H}$ ), suggesting that ECM overproduction in response to liver damage may not be exclusively related with an inflammatory/anti-inflammatory balance, but also with development of a wound healing process favored in an alternative activation microenvironment. Moreover, liver expression of TGF- $\beta 1$ (a Th2-related cytokine able to suppress the immune response and stimulate HSC activation) was discreetly increased in $\mathrm{Tc}+\mathrm{V}$ and $\mathrm{Tc}+\mathrm{CCl}_{4}$ mice, suggesting a role for HSC (Fig. 4G). Nonetheless, mRNA levels of desmin (a typical marker for activated-HSC) were not significantly modified in these same animal groups (Fig. 4I), whereas $\alpha$-sma expression (profibrogenic response-associated marker) displayed a clear 2-fold increase (Fig. 4J), which indicates a possible role for alternatively-activated Kupffer cells as wound healing promoters during the pathogenesis of liver fibrosis.

A strong alternative activation was observed in Kupffer cells isolated from $\mathrm{Tc}+\mathrm{V}$ and $\mathrm{Tc}+\mathrm{CCl}_{4}$ liver samples, as it can be seen in figure 5 . In this sense, expression of Arg-1 was significantly induced by 2.5-fold in response to T. crassiceps (Fig. 5A). Also, Kupffer cells from $\mathrm{Tc}+\mathrm{V}$ and $\mathrm{Tc}+\mathrm{CCl}_{4}$ animals showed a marked increase in the mRNA levels of $\mathrm{Ym}-1$ and FIZZ-1 by 11 and 5-fold, respectively (Fig. 5B and C). In addition, expression of MMR in these liver resident macrophages was 2-fold augmented in both Tc-inoculated groups, when compared with $\mathrm{V}$ and $\mathrm{CCl}_{4}$ subjects (Fig. 5D). Although the mRNA levels of iNOS had no significant differences throughout all studied groups, there was a clear 2.5-fold decrease in the expression of this classic activation marker in $\mathrm{Tc}+\mathrm{CCl}_{4}$ animals when compared to $\mathrm{CCl}_{4}$ mice (Fig. $5 \mathrm{E})$.

\section{Discussion}

In this work we describe that alternatively-activated Kupffer cells could be directly associated with liver fibrosis exacerbation, without necessarily inducing an active inflammatory response in this organ. Previous works have demonstrated that alternative activation of peripheral and tissue-resident macrophages is dependent on Th2-type cytokines, such as IL-4 and IL-13 [12, 13, 18]. In order to guarantee an accurate alternative Kupffer cell activation throughout the whole duration of our experiments, we used the Taenia crassiceps murine model, which due to its simplicity and reproducibility has been widely utilized for polarizing the immune cytokine pattern from the Th1-type toward a Th2-related profile in short periods of time [34-36]. 
A

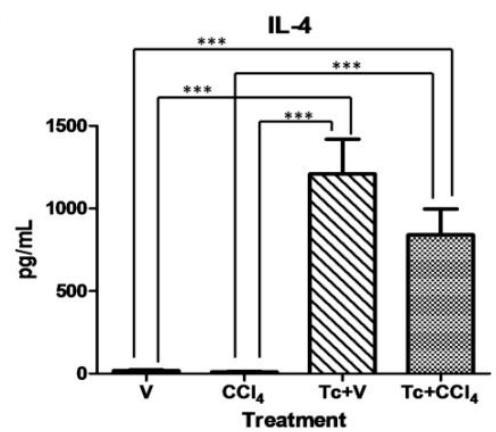

B

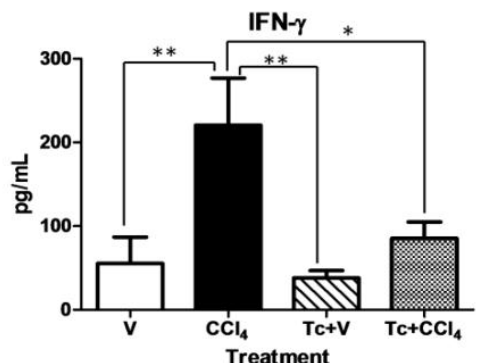

C

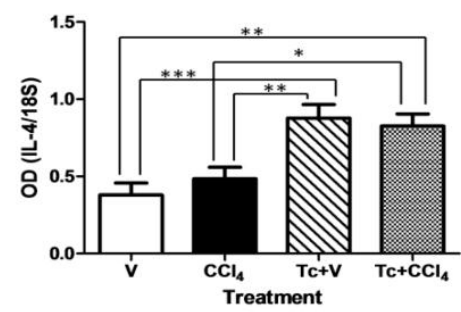

F

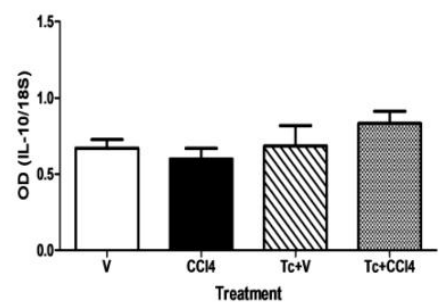

D

E
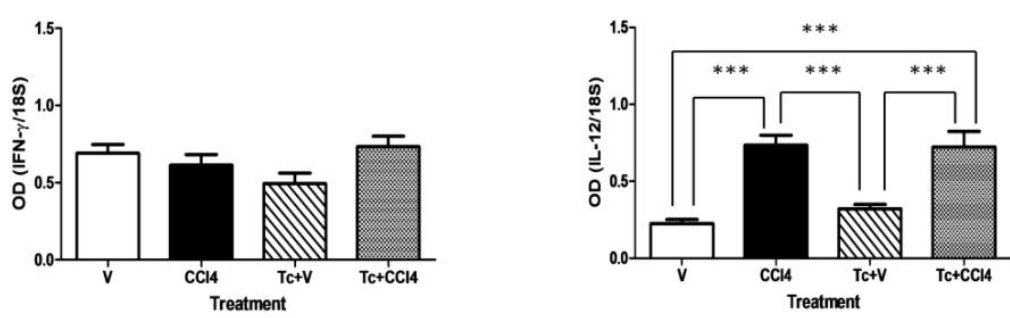

G

$\mathrm{H}$

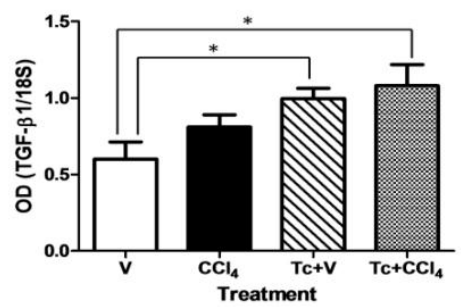

I

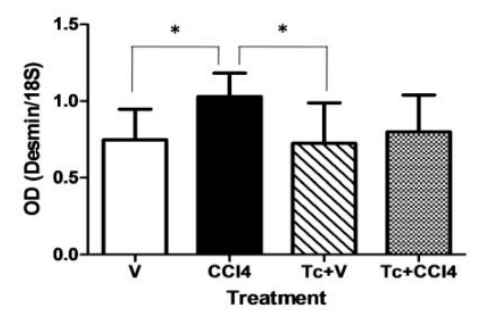

J

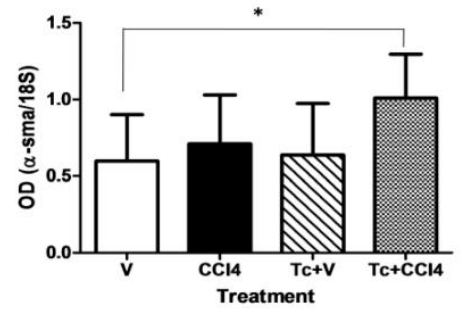

Figure 4. Th2-biased cytokine profile induces a hepatic microenvironment consistent with alternative macrophage activation. Six weeks after carbon tetrachloride or olive oil treatment, IL-4 (A) and IFN- $\gamma(B)$ serum levels were determined from all experimental groups by ELISA. mRNA levels of IL-4, IFN- $\gamma$, IL-I2, IL-10, TGF- $\beta$ I, TNF- $\alpha$, desmin, and $\alpha$-sma were directly evaluated from the hepatic tissue of all studied groups by RT-PCR. All results from $C$ to $\mathrm{J}$ are presented as optical densitometry (OD) using I8S as control gene of constitutive expression. $V=$ non-inoculated mice receiving olive oil as vehicle; $\mathrm{CCl}_{4}=$ non-inoculated mice receiving carbon tetrachloride; $\mathrm{Tc}+\mathrm{V}=$ mice previously inoculated with $T$. crassiceps receiving olive oil; $\mathrm{Tc}+\mathrm{CCl}_{4}=$ mice previously inoculated with $T$. crassiceps receiving carbon tetrachloride. Data were obtained from 2 independent experiments ( 10 animals per group), and expressed as mean \pm standard deviation. ${ }^{*} \mathrm{P}<0.05$. $* * P<0.001$. $* * * P<0.0001$. 
A

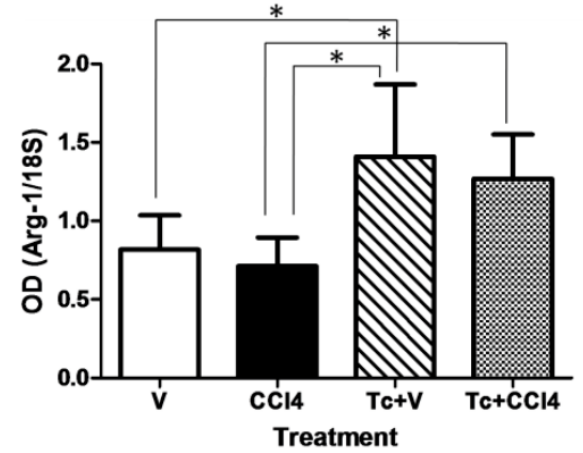

$\mathrm{C}$

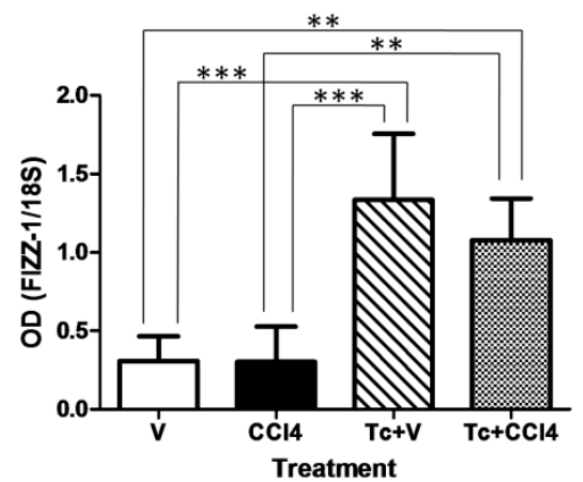

B

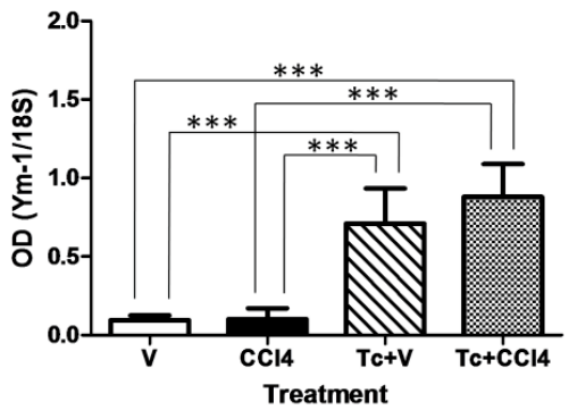

$\mathrm{D}$

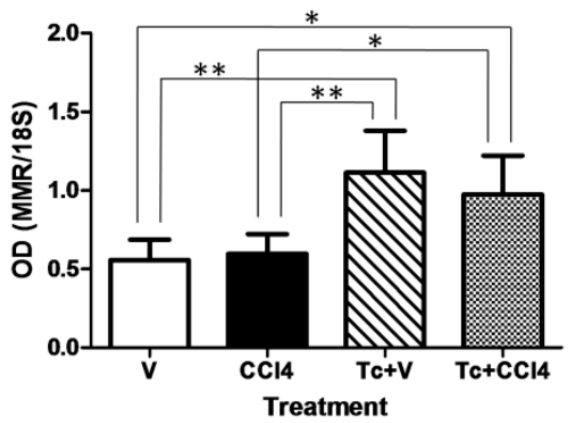

$\mathrm{E}$

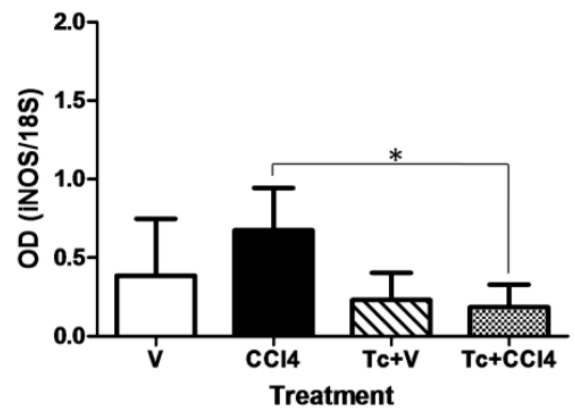

Figure 5. T. crassiceps-associated Th2 microenvironment induces alternative activation of hepatic Kupffer cells. Six weeks after carbon tetrachloride or olive oil treatment, Kupffer cells were isolated from the hepatic tissue of all experimental groups by the conventional counterflow centrifugal elutriation method. The mRNA levels of Arg-I, Ym-I, FIZZ-I, MMR, and iNOS were evaluated in those isolated Kupffer cells by RT-PCR. Results from A to $E$ are presented as optical densitometry (OD) using I8S as control gene of constitutive expression. $\mathrm{V}=$ non-inoculated mice receiving olive oil as vehicle; $\mathrm{CCl}_{4}=$ non-inoculated mice receiving carbon tetrachloride; $T c+V=$ mice previously inoculated with $T$. crassiceps receiving olive oil; $\mathrm{Tc}+\mathrm{CCl}_{4}=$ mice previously inoculated with $T$. crassiceps receiving carbon tetrachloride. Data were obtained from 2 independent experiments ( 5 animals per group), and expressed as mean \pm standard deviation. $* \mathrm{P}<0.05$. $* * \mathrm{P}<0.001$. $* * * \mathrm{P}<0.0001$. 
In fact, an extensive body of experimental evidence indicates that $T$. crassiceps-inoculated female mice are able to display a strong Th2-biased cytokine profile, characterized by elevation of IL- 4 and IL-13 serum levels with concomitant reduction in IFN- $\gamma$ in less than 6 weeks [22, 34-36]. In consequence, most of the peritoneal macrophage population is activated under a suppressive alternative phenotype, as has been extensively described $[34,37,38]$. Our results suggest that high levels of IL-4 are not only related with alternative activation on peritoneal macrophages, but also upon tissue-resident macrophages, as it is the case for hepatic Kupffer cells. In our experimental model, Kupffer cells from T. crassiceps-inoculated animals expressed a typical repertoire of alternative activation-linked markers, including Arg-1, Ym-1, FIZZ-1, and MMR, without increasing the iNOS expression. Hence, we assume that these liver-resident macrophages showed an alternative activation state at the time in which carbon tetrachloride started to be administered, and throughout the whole time of our observations.

As expected, in absence of liver damage-stimulus neither inflammation nor fibrosis were detected in the hepatic tissue of $\mathrm{V}$ subjects, even those exposed to T. crassiceps (Tc+V). On the other hand, after six weeks of carbon tetrachloride treatment, a progressive inflammatory infiltrate accompanied with moderate fibrosis $(\mathrm{F} 1-\mathrm{F} 2, \mathrm{P}<0.001)$ was observed in the liver of $\mathrm{CCl}_{4}$ mice, which is consistent with the classic concept that fibrosis is often related to hepatic damage and inflammation [5-13, 39-41]. Interestingly, our findings suggest an improvement of the local inflammation, but a simultaneous aggravation of liver fibrosis, when a polarized Th2 cytokine microenvironment is present, as it is the case for $\mathrm{Tc}+\mathrm{CCl}_{4}$ animals. These apparently controversial results can be explained from the fact that $\mathrm{Th} 2$ cytokines are able to induce alternative activation on macrophages which exhibit a high capacity of mediating both immunosuppressive and wound healing actions [32-37]. Our results indicate a systemic and local Th2-immune profile, denoted by high levels of circulating IL-4, low concentrations of IFN- $\gamma$, and hepatic expression of IL- 4 and TGF- $\beta 1$. In consequence, most of the liver-resident Kupffer cells showed an alternative phenotype consistent in overexpression of Arg-1, Ym-1, FIZZ-1, and MMR. Interestingly, FIZZ-1 and Ym-1 have been implicated in tissue remodeling and attenuation of the inflammatory response, respectively [42-43]. Additionally, Arg-1 is strongly associated with nitric oxide (NO) suppression and promotion of collagen synthesis for conversion of L-arginine into L-ornithine, and subsequently into proline [29, 32].
Although the role of alternatively-activated macrophages in immunomodulation and fibrogenesis is still controversial [16-20, 42-44], we speculate that Th2-related alternative Kupffer cells are able to exert a dual role during chronic liver injury, characterized by prevention of the inflammatory cell recruitment into the hepatic parenchyma but, at the same time, exacerbation of liver fibrosis. To our knowledge, this work is one of the first studies reporting experimental evidence suggesting that liver fibrosis is not necessarily a consequence of local chronic inflammation, but that it could also be an independent cellular process by itself, in charge of mediating injured tissue repair in response to liver damage agents.

An intriguing question involves the participation of HSC during alternative Kupffer cell activation-prompted liver fibrosis. HSC have been proposed as the main collagen-producing cells during chronic hepatic injury $[1,2]$. Once activated in response to hepatocyte necrosis, free radicals such as NO, as well as PDGF (platelet-derived growth factor), TNF- $\alpha$, and TGF- $\beta 1$, these HSC transdifferentiate into myofibroblast-like cells starting to overproduce ECM [1]. In our experiments, the mild stage of hepatic fibrosis observed in $T$. crassiceps non-inoculated mice may be related to TGF- $\beta 1$ expression, and then activation of HSC. On the other hand, although $\mathrm{Tc}+\mathrm{CCl}_{4}$ animals exhibited a significant increase in TGF- $\beta 1$ and $\alpha$-sma, no differences were detected at the hepatic expression of desmin, which has been typically associated with HSC activation [45]. Thus, our data agree with previous information demonstrating that HSC promote liver fibrosis in response to carbon tetrachloride and Th1-related proinflammatory stimulus [5, 45-47]. However, during sustained Th2-type profiles, alternatively-activated Kupffer cells may be important contributors in collagen synthesis, probably leading to an active fibrogenic state. In light of these results, the common concept that Th2 responses correlate with severe liver fibrogenesis [2, 48] could be explained, since 1) Kupffer cells are alternatively stimulated in presence of Th2-cytokines, and, 2) once activated, they show great ability to elicit local wound healing, as other authors have recently suggested during both human neuromuscular sarcoidosis, and experimental murine lung fibrosis $[49,50]$.

As mentioned, hepatic fibrosis leads to cirrhosis as a consequence of chronic liver diseases $[1,51,52]$. Furthermore, intestinal helminths are still a public health problem in developing economies [53-55]. Due to the fact that both chronic liver diseases and helminth infections are prevalent conditions in many countries from Latin America, Asia and Africa, their coexistence is highly probable. Thus, the evaluation of 
whether the presence of helminth parasites correlates with severe liver fibrosis in a more real clinical scenario is worthy of consideration, since these pathogens have exerted the ability to switch the host immune response from the Th1-profile toward a Th2-type in both mice and humans [56-58]. It is important to clarify that Kupffer cell phenotype was characterized only by means of mRNA analysis. Since posttranscriptional and posttranslational modifications can decisively influence the final outcome of most of the physiological and pathological process, further research is necessary in order to determine such Kupffer cell activation markers and cytokines at protein and protein activity levels. Finally, in addition to providing experimental evidence suggesting that alternatively-activated Kupffer cells could be capable of exacerbating liver fibrosis without inducing a local inflammatory response, our results could contribute to a better understanding of the immune mechanisms governing classic and alternative activation in these liver resident macrophages. Moreover, these findings may offer novel therapeutic targets focused on preventing a prolonged alternative activation in Kupffer cells for improving liver fibrosis and cirrhosis progression.

\section{Acknowledgments}

This work was supported by grant no. F583-Antonio Ariza Cañadilla from Fundación Mexicana para la Salud to G. Escobedo. G. López-Navarrete has a scholarship from Comisión Coordinadora de los Institutos Nacionales de Salud y Hospitales de Alta Especialidad Programa Probei. K. Suárez-Álvarez has a scholarship from CONACYT at the Programa de Posgrado en Ciencias Biológicas, UNAM. S. León-Cabrera has a scholarship from CONACYT at the Programa de Doctorado en Ciencias Biomédicas, UNAM. We thank Technician Ricardo Vargas Orozco and MVZ Daniel A. Sánchez Almaraz for their excellent care of experimental animals. Dr. Lilia Graue corrected the English version of this manuscript.

\section{Conflict of Interests}

The authors have declared that no conflict of interest exists.

\section{References}

1. Friedman SL. Liver fibrosis-from bench to bedside. J Hepatol. 2003; 38 (Suppl 1): S38-53.

2. Bataller R, Brenner DA. Liver fibrosis. J Clin Invest. 2005; 115: 209-18.

3. Parola M, Pinzani M. Hepatic wound repair. Fibrogenesis \& Tissue Repair. 2009; 2: 4.
4. Bosetti C, Levi F, Lucchini F, et al. Worldwide mortality from cirrhosis: an update to 2002. J Hepatol. 2007; 46: 827-39.

5. Higuchi H, Gores GJ. Mechanisms of liver injury: an overview. Curr Mol Med. 2003; 3: 483-90.

6. Wynn TA, Barron L. Macrophages: master regulators of inflammation and fibrosis. Semin Liver Dis. 2010; 30: 245-57.

7. Tan HH, Fiel MI, Sun Q, et al. Kupffer cell activation by ambient air particulate matter exposure may exacerbate non-alcoholic fatty liver disease. J Immunotoxicol. 2009; 6: 266-75.

8. Mandal P, Pritchard MT, Nagy LE. Anti-inflammatory pathways and alcoholic liver disease: role of an adiponectin/interleukin-10/heme oxygenase-1 pathway. J Gastroenterol. 2010; 16: 1330-6.

9. Ergün Y, Kurutas EB, Ozdil B, et al. Evaluation of nitrite/nitrate levels in relation to oxidative stress parameters in liver cirrhosis. Clin Res Hepatol Gastroenterol. 2011; 35: 303-8.

10. Luth S, Schrader J, Zander S, et al. Chronic inflammatory interferon\{gamma\}-signaling suppresses hepatocarcinogenesis in mice by sensitizing hepatocytes for apoptosis. Cancer Res 2011. [Epub ahead of print].

11. Roth S, Gong W, Gressner AM. Expression of different isoforms of TGF-beta and the latent TGF-beta binding protein (LTBP) by rat Kupffer cells. J Hepatol. 1998; 29: 915-22.

12. Odegaard JI, González R, Red Eagle A, et al. Alternative M2 activation of Kupffer cells by PPARdelta ameliorates obesity-induced insulin resistance. Cell Metab. 2008; 7: 496-507.

13. Baffy G. Kupffer cells in non-alcoholic fatty liver disease: the emerging view. Hepatol. 2009; 51: 212-23.

14. Stein M, Keshav S, Harris N, et al. Interleukin 4 potently enhances murine macrophage mannose receptor activity: a marker of alternative immunologic macrophage activation. J Exp Med. 1992; 176: 287-92.

15. Goerdt S, Politz O, Schledzewski $K$, et al. Alternative versus classical activation of macrophages. Pathobiology. 1999; 67: 222-6.

16. Wu D, Molofsky AB, Liang HE, et al. Eosinophils sustain adipose alternatively activated macrophages associated with glucose homeostasis. Science. 2011; 332: 243-7.

17. Pesce JT, Ramalingam TR, Mentink-Kane MM, et al. Arginase-1-expressing macrophages suppress Th2 cytokine-driven inflammation and fibrosis. PLoS Pathog. 2009; 5: e1000371.

18. Herbert DR, Hölscher C, Mohrs M, et al. Alternative macrophage activation is essential for survival during schistosomiasis and downmodulates $\mathrm{T}$ helper 1 responses and immunopathology. Immunity. 2004; 20: 623-35.

19. Pesce J, Kaviratne M, Ramalingam TR, et al. The IL-21 receptor augments Th2 effector function and alternative macrophage activation. J Clin Invest. 2006; 116: 2044-55.

20. Reiman RM, Thompson RW, Feng CG, et al. Interleukin-5 (IL-5) augments the progression of liver fibrosis by regulating IL-13 activity. Infect Immun. 2006; 74: 1471-9.

21. Rodriguez-Sosa M, David JR, Bojalil R, et al. Cutting edge: susceptibility to the larval stage of the helminth parasite Taenia crassiceps is mediated by Th2 response induced via STAT6 signaling. J Immunol. 2002; 168: 3135-9.

22. Kreider T, Anthony RM, Urban JF Jr, et al. Alternatively activated macrophages in helminth infections. Curr Opin Immunol. 2007; 19: 448-53.

23. Rodríguez-Sosa M, Satoskar AR, Calderón R, et al. Chronic helminth infection induces alternatively activated macrophages expressing high levels of CCR5 with low interleukin-12 production and Th2-biasing ability. Infect Immun. 2002; 70: 3656-64.

24. Stempin CC, Dulgerian LR, Garrido VV, et al. Arginase in parasitic infections: macrophage activation, immunosuppression, 
and intracellular signals. J Biomed Biotechnol. 2010; 2010: 683485.

25. Nair MG, Du Y, Perrigoue JG, et al. Alternatively activated macrophage-derived RELM-\{alpha\} is a negative regulator of type 2 inflammation in the lung. J Exp Med. 2009; 206: 937-52.

26. Stein $\mathrm{M}, \mathrm{Keshav} \mathrm{S}$, Harris $\mathrm{N}$, et al. Interleukin 4 potently enhances murine macrophage mannose receptor activity: a marker of alternative immunologic macrophage activation. J Exp Med. 1992; 176: 287-92.

27. Reyes JL, Espinoza-Jiménez AF, González MI, et al. Taenia crassiceps infection abrogates experimental autoimmune encephalomyelitis. Cell Immunol. 2011; 267: 77-87.

28. Espinoza-Jiménez A, Rivera-Montoya I, Cárdenas-Arreola R, et al. Taenia crassiceps infection attenuates multiple low-dose streptozotocin-induced diabetes. J Biomed Biotechnol. 2010; 2010: 850541.

29. Daley JM, Brancato SK, Thomay AA, et al. The phenotype of murine wound macrophages. J Leukoc Biol. 2010; 87: 59-67.

30. Gratchev A, Guillot P, Hakiy N, et al. Alternatively activated macrophages differentially express fibronectin and its splice variants and the extracellular matrix protein betaIG-H3. Scand J Immunol. 2001; 53: 386-92.

31. Classen A, Lloberas J, Celada A. Macrophage activation: classical versus alternative. Methods Mol Biol. 2009; 531: 29-43.

32. Yeramian A, Martin L, Serrat N, et al. Arginine transport via cationic amino acid transporter 2 plays a critical regulatory role in classical or alternative activation of macrophages. J Immunol. 2006; 176: 5918-24.

33. Freeman FS. Studies on the biology of Taenia crassiceps (zeder 1800) rudolphi, 1810 (cestoda). Can J Zool. 1962; 40: 969-990.

34. Koning N, van Eijk M, Pouwels W, et al. Expression of the inhibitory CD200 receptor is associated with alternative macrophage activation. J Innate Immun. 2010; 2: 195-200.

35. Van den Bossche J, Bogaert $\mathrm{P}$, van Hengel J, et al. Alternatively activated macrophages engage in homotypic and heterotypic interactions through IL-4 and polyamine-induced E-cadherin/catenin complexes. Blood. 2009; 114: 4664-74.

36. Terrazas LI, Bojalil R, Govezensky T, et al. Shift from an early protective Th1-type immune response to a late permissive Th2-type response in murine cysticercosis (Taenia crassiceps). J Parasitol. 1998; 84: 74-81.

37. Reyes JL, Terrazas CA, Alonso-Trujillo J, et al. Early removal of alternatively activated macrophages leads to Taenia crassiceps cysticercosis clearance in vivo. Int J Parasitol. 2010; 40: 731-42.

38. Terrazas LI. The complex role of pro- and anti-inflammatory cytokines in cysticercosis: immunological lessons from experimental and natural hosts. Curr Top Med Chem. 2008; 8: 383-92.

39. Tsai CF, Hsu YW, Chen WK, et al. Hepatoprotective effect of electrolyzed reduced water against carbon tetrachloride-induced liver damage in mice. Food Chem Toxicol. 2009; 47: 2031-6.

40. Jang JH, Kang KJ, Kim YH, et al. Reevaluation of experimental model of hepatic fibrosis induced by hepatotoxic drugs: an easy, applicable, and reproducible model. Transplant Proc. 2008; 40: 2700-3.

41. Fang HL, Lin HY, Chan MC, et al. Treatment of chronic liver injuries in mice by oral administration of ethanolic extract of the fruit of Hovenia dulcis. Am J Chin Med. 2007; 35: 693-703.

42. Mishra A, Wang M, Schlotman J, et al. Resistin-like molecule-b is an allergen-induced cytokine with inflammatory and remodeling activity in the murine lung. Am J Physiol Lung Cell Mol Physiol. 2007; 293: L305-L313.

43. Menzies FM, Henriquez FL, Alexander J, et al. Sequential expression of macrophage anti-microbial/inflammatory and wound healing markers following innate, alternative and classical activation. Clin Exp Immunol. 2010; 160: 369-79.
44. Hunter MM, Wang A, Parhar KS, et al. In vitro-derived alternatively activated macrophages reduce colonic inflammation in mice. Gastroenterology. 2010; 138: 1395-405.

45. Österreicher CH, Penz-Österreicher M, Grivennikov SI, et al. Fibroblast-specific protein 1 identifies an inflammatory subpopulation of macrophages in the liver. Proc Natl Acad Sci U S A. $2011 ; 108: 308-13$.

46. Canbay A, Friedman S, Gores GJ. Apoptosis: the nexus of liver injury and fibrosis. Hepatology. 2004; 39: 273-8.

47. Casini A, Ceni E, Salzano R, et al. Neutrophil-derived superoxide anion induces lipid peroxidation and stimulates collagen synthesis in human hepatic stellate cells: role of nitric oxide. Hepatology. 1997; 25: 361-7.

48. Shi Z, Wakil AE, Rockey DC, et al. Strain-specific differences in mouse hepatic wound healing are mediated by divergent $\mathrm{T}$ helper cytokine responses. Proc Natl Acad Sci U S A. 1997; 94: 10663-8.

49. Murray LA, Chen Q, Kramer MS, et al. TGF-beta driven lung fibrosis is macrophage dependent and blocked by Serum amyloid P. Int J Biochem Cell Biol. 2011; 43: 154-62.

50. Prokop S, Heppner FL, Goebel HH, et al. M2 polarized macrophages and giant cells contribute to myofibrosis in neuromuscular sarcoidosis. Am J Pathol. 2011; 178: 1279-86.

51. Kershenobich D. [A vision of future treatment of liver diseases]. Rev Gastroenterol Mex. 2004; 69 (Suppl 3): 171-2.

52. Gutiérrez-Ruíz MC, Robles-Díaz G, Kershenobich D. Emerging concepts in inflammation and fibrosis. Arch Med Res. 2002; 33: 595-9.

53. Kanoa BJ, Hamed AT, Zabut BM, et al. Prevalence of malnutrition and intestinal parasites among preschool children in the Gaza strip. J Egypt Soc Parasitol. 2010; 40: 383-94.

54. Hotez PJ, Brindley PJ, Bethony JM, et al. Helminth infections: the great neglected tropical diseases. J Clin Invest. 2008; 118: 1311-21.

55. Cooper PJ, Ayre G, Martin C, et al. Geohelminth infections: a review of the role of $\mathrm{IgE}$ and assessment of potential risks of anti-IgE treatment. Allergy. 2008; 63: 409-17.

56. Soonawala D, Geerts JW, de Mos M, et al. The immune response to schistosome antigens in formerly infected travelers. Am J Trop Med Hyg. 2011; 84: 43-7.

57. Koyasu S, Moro K, Tanabe M, et al. Natural helper cells: a new player in the innate immune response against helminth infection. Adv Immunol. 2010; 108: 21-44.

58. Wright VJ, Ame SM, Haji HS, et al. Early exposure of infants to GI nematodes induces Th2 dominant immune responses which are unaffected by periodic anthelminthic treatment. PLoS Negl Trop Dis. 2009; 3: e433. 